\title{
GENOTOXIC EFFECT OF GALLIC AND ELLAGIC ACIDS IN SOMATIC AND GERM CELLS OF DROSOPHILA MELANOGASTER
}

\author{
Sanja LJ. Matić*, Snežana M. Stanić and Milica M. Kanjevac \\ University of Kragujevac, Faculty of Science, Department of Biology and Ecology, \\ Radoja Domanovića 12, 34000 Kragujevac, Serbia \\ *Corresponding author; E-mail: sanjamatic@kg.ac.rs
}

(Received March 5th, 2019; Accepted April 1st, 2019)

\begin{abstract}
Phenolic acids are a large class of compounds occur naturally in a variety of plants and exhibit a wide range of biological activities, but toxic effects have also been observed. This study was designed to assess genotoxic effect of two selected phenolic acids, gallic and ellagic, in somatic and germ cells of Drosophila melanogaster using the sex-linked recessive lethal (SLRL) test and comet assay in vivo. The obtained results revealed that tested phenolic acids did not induce genotoxic effect and therefore have a safety margin for therapeutic use.
\end{abstract}

Key words: ellagic acid, gallic acid, Drosophila melanogaster, genotoxicity

\section{INTRODUCTION}

The therapeutic effects of many plants have been assigned to the presence of phenolic acids such as cichoric acid, echinacoside, chlorogenic acid (LETCHAMO et al., 1999). The naturally occurring phenolic acids have been investigated in the prevention and treatment a wide range of ailments. Various reports have shown beneficial effects of phenolic acids such as cytoprotective (VIEIRA et al., 1998), neuroprotective (MANSOURI et al., 2013; IBRAHIM et al., 2015), anticancer (TANAKA et al., 1998; BAEZA et al., 2014), antimicrobial (ANTONIO et al., 2011; ALMEIDA et al., 2012), and antidiabetic (GHASEMZADEH and GHASEMZADEH, 2011; PADMA et al., 2011).

In addition to known activity, phenolic acids have been tested in order to assess genotoxic and potential antigenotoxic activities. Phenolic acids, as ferulic, caffeic and gentisic, are known to exhibit protective effect against the genotoxicity of acridin orange and ofloxacin in Salmonella typhimurium and Euglena gracilis (KRIŽKOVÁ et al., 2000; BELICOVÁ et al., 2001; BIROŠOVÁ et al., 2005). YAMADA and TOMITA (1996) described that caffeic and chlorogenic acid possesses inhibitory effect on the mutagenicity of 3-amino-1,4-dimethyl-5 $\mathrm{H}$ pyrido[4,3-b]indole (Trp-P-1), and 2-aminodipyrido[1,2-a:3',2'-d]imidazole (Glu-P-2). These phenolic acids may inhibit the formation of $\mathrm{N}$-nitroso compounds because they are inhibitors of the N-nitrosation reaction in vitro (KONO et al., 1995). VATTEM et al. (2006) demonstrated that rosmarinic acid inhibited the mutagenic potential of sodium azide and N-methyl-N'-nitro$\mathrm{N}$-nitrosoguanidine in the Salmonella typhimurium test system. Also, rosmarinic acid reduced 
the frequency of micronuclei in human lymphocytes (SÁNCHEZ-CAMPILLO et al., 2009) and in V79 cells (FURTADO et al., 2010). Furthermore, rosmarinic acid showed antigenotoxic effects against ethanol in mice peripheral blood and brain cells (DE OLIVEIRA et al., 2012) and in Wistar rat brain tissue or peripheral blood using the comet assay (PEREIRA et al., 2005).

The results concerning the genotoxic effect of phenolic acids are contradictory. Not all phenolic acids are necessarily beneficial, some of them have genotoxic effect. According to MAISTRO et al. (2011) caffeic, cinnamic and ferulic acids exhibited the genotoxic potential in rat hepatoma tissue cells (HTCs) using the in vitro micronucleus assays. Cichoric acid showed mutagenic activity in the Ames test with Salmonella typhimurium TA98 and TA100 strains (MIKULÁŠOVÁ et al., 2005) while caffeic acid and chlorogenic acid induced mutations in TA102 strain.

The in vivo study by El HAJJOuJI et al. (2007) demonstrated the genotoxic effect for gallic acid using Vicia faba micronucleus test. Also, genotoxic effect has been reported for gallic acid by sex-linked recessive lethal test in Drosophila melanogaster (STANIĆ et al., 2009). LABIENIEC and GABRYELA (2003) previously reported that tannic, ellagic and gallic acids have genotoxic and cytotoxic properties in the Chinese hamster cells.

Gallic acid, a naturally occurring compound, and ellagic acid, a dimeric derivative of gallic acid, have been commonly found in gallnuts, tea, tree barks, herbs, flowers, fruits and vegetables including cranberry, blackberry, blackcurrant, strawberry, and raspberry (BREWER, 2011; NAKAMURA et al., 2012; SINGH et al., 2013). Various studies have shown a positive effect for ellagic and gallic acids such as antioxidant, antimutagenic and anticancer properties (SALDANHA et al., 2018). LOARCA-PIÑA et al. (1996) tested the antimutagenicity of ellagic acid against the aflatoxin B1 used the Salmonella microsuspension assay. Also, AYRTON et al. (1992) evaluated ability of ellagic acid to inhibit the mutagenicity of the food mutagen 2amino-3-methylimadazo[4,5-f]-quinoline (IQ) using Ames test.

Despite the potential of the gallic and ellagic acids, there have very little studies on the possible genotoxic effects of these natural compounds. Therefore, the aim of this study was to evaluate the genotoxic activity of these two phenolic compounds in Drosophila melanogaster, using the comet and SLRL assays.

\section{MATERIALS AND METHODS}

\section{Chemicals}

All chemicals and reagents used for analyses of genotoxic effect were of analytical grade. Phosphate-buffered saline (PBS) without calcium and magnesium, agarose for DNA electrophoresis, low-melting point agarose (LMA), and collagenase were obtained from Alfatrade Enterprise D.O.O.; methyl 4-hydroxybenzoate, ethyl methanesulphonate (EMS) and gallic acid (CAS 149-91-7, technical grade > 98.0\%) were purchased from Sigma-Aldrich, St. Louis, MO, USA and ellagic acid (CAS 133039-73-3, technical grade > 98.0\%) was obtained TCI, Tokyo Chemical Industry CO., LTD.

\section{Fly strain}

Flies and larvae of wild type strain of Drosophila melanogaster (Canton S, available from Bloomington Stock Center, Indiana, USA) were cultured at $25^{\circ} \mathrm{C}, 60 \%$ humidity and a 12:12 h light/dark regime on standard corn medium containing agar, sugar and yeast.

\section{SLRL test}

In the negative control group 30 males were exposed to $1 \%$ sucrose. The positive control group was treated with $0.75 \mathrm{ppm}$ ethylmethane sulfonate (EMS). The third and fourth 
groups were treated with a $100 \mathrm{ppm}$ of gallic or ellagic acids dissolved in sucrose. The standard procedure for the detection of sex linked recessive lethal mutations on $D$. melanogaster was applied (WÜRGLER and GRAF, 1985) as previously described in detail in MLADENOVIĆ et al. (2013).

\section{Comet test}

Third instars larvae of D. melanogaster (20 larvae per group) were divided into four groups. A negative control group, without treatment, received standard Drosophila diet while a positive control group treated only with ethyl methanesulphonate (EMS, $5 \mathrm{mM}$ in PBS). In order to determine the potential for gallic and ellagic acids to damage DNA in somatic cells, the larvae of $D$. melanogaster were fed with the medium containing $1 \mathrm{mM}$ gallic or ellagic acid for $24 \mathrm{~h}$. The comet assay was performed according to SINGH et al. (1988) with minor modifications as described by MUKHOPADHYAY et al. (2004). Immediately before use slides were stained with $80 \mathrm{~mL}$ of ethidium bromide $(20 \mathrm{mg} / \mathrm{mL})$. The images were visualized and captured with 40x objective lens of fluorescence microscope Nikon (Ti-Eclipse) attached to CCD camera. One hundred randomly selected cells (50 cells per two replicate slides) were analyzed per treatment. The DNA damage was quantified as percentage of DNA in the comet tail.

\section{Statistical analysis}

A statistically significant difference in lethal cultures in the SLRL test was found for large independent samples by testing the difference between proportions (PETZ, 1985). The results in the Comet test were expressed as mean \pm SEM and a statistical evaluation of the data was carried out by means of one-way analysis (ANOVA) using the SPSS statistical software package, version 13.0 for Windows. The significance level was set at $\mathrm{p}<0.05$.

\section{RESULTS AND DISCUSSION}

The genotoxicity of gallic and ellagic acids was evaluated in vivo in germ and somatic cells of D. melanogaster by the SLRL and Comet tests. As shown in Tab. 1 EMS significantly increased the frequency of germinative mutations compared with the untreated control in all the three broods. There were no statistically significant differences in the frequency of germinative mutations between the males treated with gallic acid (Tab. 1) and the males in the control group (1\% sucrose). Compared to the males in the positive control group, the males treated with gallic acid showed a statistically significant difference.

The results of the SLRL test performed in D. melanogaster males showed no genotoxic activity of ellagic acid (Tab. 2). The increase in number of lethal was observed in the EMS treated group and no increase in the number of lethal in the ellagic acid treated group.

Contrary to our results, El HAJJOUJI et al. (2007) reported the genotoxic activity of gallic acid in Vicia faba micronucleus test. Furthermore, LABIENIEC and GABRYELA (2003) reported that ellagic and gallic acids has genotoxic effect in the Chinese hamster cells and in human carcinoma cells (WENG et al., 2015)

Also, we have previously described the genotoxic activity of the gallic acid in concentration of 5\% using SLRL test (STANIĆ et al., 2009) in D. melanogaster. Our results indicate that the genotoxic effect of gallic acid occurs in a concentration-dependent manner. There are cases where low concentrations of polyphenols cause DNA protection whereas high concentrations of the same compounds cause DNA damage (WÄTJEN et al., 2005). 
Table 1. Frequencies of sex linked recessive lethal mutations after the treatment with gallic acid.

\begin{tabular}{lcccccc}
\hline & \multicolumn{7}{c}{ Treatment } \\
\cline { 2 - 7 } & $\mathbf{S}^{\mathbf{a}}$ & $\mathbf{E M S}^{\mathbf{b}}$ & $\mathbf{G A}^{\mathbf{c}}$ & $\mathbf{t}_{\mathbf{S} / \mathrm{EMS}}$ & $\mathbf{t}_{\mathbf{S} / \mathrm{GA}}$ & $\mathbf{t}_{\text {EMS/GA }}$ \\
\hline I brood $\boldsymbol{\Sigma}$ & 92 & 104 & 52 & 8.3 & 0.36 & 8.23 \\
No of lethal & 12 & 64 & 6 & $\mathrm{p}<0.001^{* * *}$ & $\mathrm{p}>0.05$ & $\mathrm{p}<0.001^{* * *}$ \\
\% of lethal & 13.04 & 61.5 & 11.5 & & & \\
II brood $\boldsymbol{\Sigma}$ & 96 & 90 & 48 & 6.7 & 1.6 & 3.5 \\
No of lethal & 10 & 44 & 10 & $\mathrm{p}<0.001^{* * *}$ & $\mathrm{p}>0.05$ & $\mathrm{p}<0.001^{* * *}$ \\
\% of lethal & 10.04 & 48.9 & 20.8 & & & \\
III brood $\boldsymbol{\Sigma}$ & 64 & 108 & 42 & 5.3 & 0.8 & 3.9 \\
No of lethal & 6 & 44 & 6 & $\mathrm{p}<0.001^{* * *}$ & $\mathrm{p}>0.05$ & $\mathrm{p}<0.001^{* * *}$ \\
\% of lethal & 9.4 & 40.7 & 14.3 & & & \\
I+II+III $\boldsymbol{\Sigma}$ & 252 & 302 & 142 & 13.3 & 1.1 & 8.7 \\
No of lethal & 28 & 152 & 22 & $\mathrm{p}<0.001^{* * *}$ & $\mathrm{p}>0.05$ & $\mathrm{p}<0.001^{* * *}$ \\
\% of lethal & 11.1 & 50.3 & 15.5 & & & \\
\hline
\end{tabular}

Triple asterix indicates significantly higher frequency compared to EMS as positive control or to sucrose as negative control. Statistically significant differences: $p<0.001 * * *$

${ }^{\mathrm{a}} \mathrm{S}$; sucrose; negative control, $1 \%$. ${ }^{\mathrm{b}} \mathrm{EMS}$; ethyl methanesulfonate, positive control, $0.75 \mathrm{ppm}$.

${ }^{\mathrm{c}} \mathrm{GA}$; gallic acid, $100 \mathrm{ppm}$.

Table 2. Frequencies of sex linked recessive lethal mutations after the treatment with ellagic acid

\begin{tabular}{lcccccc}
\hline & \multicolumn{7}{c}{ Treatment } \\
\cline { 2 - 7 } & $\mathbf{S}^{\mathbf{a}}$ & $\mathbf{E M S}^{\mathbf{b}}$ & $\mathbf{E A}^{\mathbf{c}}$ & $\mathbf{t}_{\text {S/EMS }}$ & $\mathbf{t}_{\text {S/EA }}$ & $\mathbf{t}_{\text {EMS/EA }}$ \\
\hline I brood $\boldsymbol{\Sigma}$ & 92 & 104 & 54 & 8.3 & 0.95 & 6.14 \\
No of lethal & 12 & 64 & 10 & $\mathrm{p}<0.001^{* * *}$ & $\mathrm{p}>0.05$ & $\mathrm{p}<0.001^{* * *}$ \\
\% of lethal & 13.04 & 61.5 & 18.5 & & & \\
II brood $\boldsymbol{\Sigma}$ & 96 & 90 & 44 & 6.7 & 0.7 & 4.4 \\
No of lethal & 10 & 44 & 6 & $\mathrm{p}<0.001 * * *$ & $\mathrm{p}>0.05$ & $\mathrm{p}<0.001 * * *$ \\
\% of lethal & 10.4 & 48.9 & 13.6 & & & \\
III brood $\boldsymbol{\Sigma}$ & 64 & 108 & 30 & 5.3 & 1.4 & 2.7 \\
No of lethal & 6 & 44 & 6 & $\mathrm{p}<0.001^{* * *}$ & $\mathrm{p}>0.05$ & $\mathrm{p}<0.01 * *$ \\
\% of lethal & 9.4 & 40.7 & 20 & & & \\
I+II+III $\boldsymbol{\Sigma}$ & 252 & 302 & 128 & 13.3 & 1.5 & 8.3 \\
No of lethal & 28 & 152 & 22 & $\mathrm{p}<0.001^{* * *}$ & $\mathrm{p}>0.05$ & $\mathrm{p}<0.001^{* * *}$ \\
\% of lethal & 11.1 & 50.3 & 17.2 & & & \\
\hline
\end{tabular}

Triple asterix indicates significantly higher frequency compared to EMS as positive control or to sucrose as negative control. Statistically significant differences: $\mathrm{p}<0.01 * *, \mathrm{p}<0.001 * * *$

${ }^{\mathrm{a}} \mathrm{S}$; sucrose; negative control, $1 \%$. ${ }^{\mathrm{b}} \mathrm{EMS}$; ethyl methanesulfonate, positive control, $0.75 \mathrm{ppm}$.

${ }^{\mathrm{c}} \mathrm{EA}$; ellagic acid, $100 \mathrm{ppm}$.

The effects of the positive controls (EMS, $5 \mathrm{mM}$ in $\mathrm{PbS}$ ) and two phenolic acids (1 $\mathrm{mM}$ ) on selected comet parameter and third instars larvae of D. melanogaster are presented in Tab. 3.

The percentages of DNA in tail were significantly higher in the group treated with 5 $\mathrm{mM}$ EMS than in the negative control $(\mathrm{p}<0.05)$. The data demonstrate that tested phenolic acids did not cause an increase of the DNA damage. Ellagic acid induced only a slight increase in the \% DNA in tail. The statistical analysis of these data confirms that the concentration of $1 \mathrm{mM}$ of ellagic acid induced a minimum level of DNA damage after $24 \mathrm{~h}$ of treatment and that this DNA damage was less in comparison with those caused by the $5 \mathrm{mM}$ EMS. 
Table 3. Genotoxic effect of gallic and ellagic acids using comet assay

\begin{tabular}{cc}
\hline Treatment $^{\mathrm{a}}$ & \% DNA in tail \\
\hline NC $^{\mathbf{b}}$ & $5.4 \pm 0.61^{\dagger}$ \\
EMS $^{\mathbf{c}}$ & $61.5 \pm 1.2^{*}$ \\
$\mathbf{G A}^{\mathbf{d}}$ & $6.2 \pm 0.5^{\dagger}$ \\
$\mathbf{E A}^{\mathbf{e}}$ & $8.04 \pm 0.62^{* \dagger}$
\end{tabular}

${ }^{\mathrm{a}}$ Data are presented as the means \pm SEM obtained from three independent experiments.

${ }^{\mathrm{b}} \mathrm{NC}$; negative control. ${ }^{\mathrm{c}} \mathrm{EMS}$, ethyl methanesulfonate, $5 \mathrm{mM}$. ${ }^{\mathrm{d}} \mathrm{GA}$, gallic acid, $1 \mathrm{mM}$.

${ }^{\mathrm{e}} \mathrm{EA}$, ellagic acid, $1 \mathrm{mM} .{ }^{*} \mathrm{p}<0.05$ when compared with the negative control group ${ }^{\dagger} \mathrm{p}<0.05$ when compared with the positive control group.

According to the data obtained in the SLRL test and Comet assay, the selected phenolic acids did not cause DNA damage suggesting that they did not present genotoxicity. These results are in accordance with earlier studies that reported the absence of genotoxic effect of ellagic and gallic acids using the in vitro Ames test (CHEN AND CHUNG, 2000; OKUDA, 2005; SiLVA et al., 2014) and comet test (FERK et al., 2011). Similarly, study by BERNI et al. (2012) has reported that ellagic acid did not increase the frequency of polychromatic erythrocytes in Swiss albino mice.

In conclusion, exposure of males in SLRL test and larvae in comet test to gallic and ellagic acids did not produce genotoxic effect. The results of this research showed that further in vivo studies with other model organisms are needed before definitive conclusions about the absence of genotoxic potential of tested phenolic acids.

\section{Acknowledgments}

This work was supported by the Ministry of Education, Science and Technological Development, Republic of Serbia, Grants No. III43004 and III41010.

\section{References:}

[1] Almeida, A.A.P., Naghetini, C.C., Santos, V.R., Antonio, A.G., Farah, A., GLORIA, M.B.A. (2012): Influence of natural coffee compounds, coffee extracts and increased levels of caffeine on the inhibition of Streptococcus mutans. Food Research International 49: 459-461. doi: 10.1016/j.foodres.2012.07.026

[2] Antonio, A.G., Lorio, N.L.P., Pierro, V.S.S., Canderva, M.S., Farah, A., SANTos, K.R.N., MAIA, L.C. (2011): Inhibitory properties of Coffea canephora extract against oral bacteria and its effect on demineralisation of deciduous teeth. Archives of Oral Biology 56: 556-564. doi: 10.1016/j.archoralbio.2010.12.001.

[3] Ayrton, A.D., Lewis, D.F., Walker, R., IOAnnides, C. (1992): Antimutagenicity of ellagic acid towards the food mutagen IQ: investigation into possible mechanisms of action. Food and Chemical Toxicology 30(4): 289-295.

[4] Baeza, G., Amigo-Benevent, M., Sarria, B., Goya, L., Mateos, R., Bravo, L. (2014): Green coffee hydroxycinnamic acids but not caffeine protect human HepG2 cells against oxidative stress. Food Research International 62: 1038-1046. doi:10.1016/j.foodres.2014.05.035 
[5] BelicovÀ, A., KrižKova, L., Nagy, M., KrajČovič, J., Ebringer, L. (2001): Phenolic acids reduce the genotoxicity of acridine orange and ofloxacin in Salmonella typhimurium TA 102. Folia Microbiologica 47: 511-514.

[6] Berni, A., Grossi, M.R., Pepe, G., FilipPi, S., Muthukumar, S., Papeschi, C., NAtara-Jan, A.T., PALiTti, F. (2012): Protective effect of ellagic acid (EA) on micronucleus formation induced by N-methyl-N'-nitro-N-nitrosoguanidine (MNNG) in mammalian cells, in in vitro assays and in vivo. Mutation Research 746: 60-65. doi: 10.1016/j.mrgentox.2012.03.007.

[7] BirošovÀ, L., MikulášovÀ, M., VAVERKovÁ, Š. (2005): Antimutagenic effect of phenolic acids. Biomedical Papers 149(2): 489-491.

[8] BREWER, M.S. (2011): Natural antioxidants: Sources, compounds, mechanisms of action, and potential applications. Comprehensive Reviews in Food Science and Food Safety 10: 221-247. doi: 10.1111/j.1541-4337.2011.00156.x

[9] ChEn, S.C., Chung, K.T. (2000): Mutagenicity and antimutagenicity studies of tannic acid and its related compounds. Food and Chemical Toxicology 38: 1-5.

[10] De Oliveira, N.C., Sarmento, M.S., Nunes, E.A., Porto, C.M., Rosa, D.P., Bona, S.R., Rodrigues, G., Marroni, N.P., Pereira, P., Picada, J.N., Ferraz, A.B., ThIESEN, F.V., DA Silva, J. (2012): Rosmarinic acid as a protective agent against genotoxicity of ethanol in mice. Food and Chemical Toxicology 50: 1208-1214. doi: 10.1016/j.fct.2012.01.028

[11] El Hajuouji, H., Pinelli, E., Guiresse, M., Merlina, G., Revel, J.C., Hafidi, M. (2007): Assessment of the genotoxicity of olive mill waste water (OMWW) with the Vicia faba micronucleus test. Mutation Research 634: 25-31. doi: 10.1016/j.mrgentox.2007.05.015

[12] Ferk, F., Chakraborty, A., Jäger, W., Kundi, M., Bichler, J., Miší́, M., W Agner, K.H., Grasl-Kraupp, B., Sagmeister, S., Haidinger, G., Hoelzl, C., Nersesyan, A., DuŠInsKÁ, M., SIMIĆ, T., KNASMÜLler, S. (2011): Potent protection of gallic acid against DNA oxidation: Results of human and animal experiments. Mutation Research/Fundamental and Molecular Mechanisms of Mutagenesis 715: 61-71. doi: 10.1016/j.mrfmmm.2011.07.010

[13] Furtado, R.A., de Araújo, F.R., Resende, F.A., Cunha, W.R., Tavares, D.C. (2010): Protective effect of rosmarinic acid on V79 cells evaluated by the micronucleus and comet assays. Journal of Applied Toxicology 30: 254-259. doi: 10.1002/jat.1491

[14] Ghasemzadeh, A., Ghasemzadeh, N. (2011): Flavonoids and phenolic acids: role and biochemical activity in plants and human. Journal of Medicinal Plants Research 5(31): 6697-6703. doi: 10.5897/JMPR11.1404

[15] Ibrahim, A.E., Kareem, R.A.E., Sheir, M.A. (2015): Elucidation of acrylamide genotoxicity and neurotoxicity and the protective role of gallic acid and green tea. Journal of Forensic Toxicology and Pharmacology 4: 1-6. doi:10.4172/23259841.1000135

[16] Kono, Y., Shibata, H., Kodama, Y., Sawa,Y. (1995): The suppression of the Nnitrosating reaction by chlorogenic acid. Biochemical Journal 312: 947-953. doi: $10.1042 / \mathrm{BJ} 3120947$

[17] KrižKová, L., Nagy, M., Polónyi, J., Dobias, J., Belicová, A., GranČai, D., KRAJČOVIČ, J. (2000): Phenolic acids inhibit chloroplast mutagenesis in Euglena gracilis. Mutation Research 469: 107-114. 
[18] LABIENIEC, M., GABRyela, T. (2003): Effects of tannins on Chinese hamster cell line B14. Mutation Research 539: 127-135.

[19] Letchamo, W., Livesey, J., Arnason, T.J., Bergeron, C., Krutilina, V.S. (1999): Cichoric acid and isobutylamide content in Echinacea purpurea as influenced by flower developmental stages. In: Janick, J. (ed). Perspectives on new crops and new uses. Alexandria: ASHS Press, 494-498 pp.

[20] Loarca-Pina, G., Kuzmicky, P.A., De-Mejia, E.J., KodA, N.Y., Hsieh, D.P.H. (1996): Antimutagenicity of ellagic acid against aflatoxin B1 in the Salmonella microsuspension assay. Mutation Research 360(1): 15-21.

[21] Maistro, E.L., Angeli, J.P., Andrade, S.F., Mantovani, M.S. (2011): In vitro genotoxicity assessment of caffeic, cinnamic and ferulic acids. Genetics and Molecular Research 10 (2): 1130-1140. doi: 10.4238/vol10-2gmr1278

[22] Mansouri, M.T., Farbood, Y., Sameri, M.J., Sarkaki, A., Naghizadeh, B., RAFEIRAD, M. (2013): Neuroprotective effects of oral gallic acid against oxidative stress induced by 6-hydroxydopamine in rats. Food Chemistry 138: 1028-1033. doi: 10.1016/j.foodchem.2012.11.022

[23] Mikulášová, M., Vaverková, Š., Birošová, L., Suchánová, M. (2005): Genotoxic effects of the hydroxycinnamic acid derivatives-caffeic, chlorogenic and cichoric acids. Biologia 60(3): 275-279

[24] Mladenović, M., Matić, S., Stanić, S., Solujić, S., Mihailović, V., Stanković, N., KATANić, J. (2013): Combining molecular docking and 3-D pharmacophore generation to enclose the in vivo antigenotoxic activity of naturally occurring aromatic compounds: Myricetin, quercetin, rutin, and rosmarinic acid. Biochemical Pharmacology 86(9): 1376-1396. doi: 10.1016/j.bcp.2013.08.018

[25] Mukhopadhyay, I., Chowdhuri, D.K., Bajpayee, M., Dhawan, A. (2004): Evaluation of in vivo genotoxicity of cypermethrin in Drosophila melanogaster using the alkaline comet assay. Mutagenesis 19(2): 85-90. doi: 10.1093/mutage/geh007

[26] NAKAmura, K., YAmada, Y., IKaI, H., KanNO, T., SASAKI, K. (2012): Bactericidal Action of Photoirradiated Gallic Acid via Reactive Oxygen Species Formation. Journal of Agricultural and Food Chemistry 60(40): 10048-1064. doi: $10.1021 / \mathrm{jf} 303177 \mathrm{p}$

[27] OKUDA, T. (2005): Systematics and health effects of chemically distinct tannins in medicinal plants. Phytochemistry 66(17): 2012-2031. doi: 10.1016/j.phytochem.2005.04.023

[28] Padma, V.V., Sowmya, P., Felix, T.A., Baskaran, R., Poornima, P. (2011): Protective effect of gallic acid against lindane induced toxicity in experimental rats. Food and Chemical Toxicology 49(4): 991-998. doi: 10.1016/j.fct.2011.01.005

[29] Pereira, P., Tysca, D., Oliveira, P., DA Silva Brum, L.F., PicAdA, J.N., Ardenghi, P. (2005): Neurobehavioral and genotoxic aspects of rosmarinic acid. Pharmacological Research 52(3): 199-203. doi: 10.1016/j.phrs.2005.03.003

[30] Petz, B. (1985): Basic statistical method for non-mathematical use. SNL Zagreb, Croatia.

[31] Saldanha, E., RaO, S., Adnan, M., Pais, M.L.J., Naik, T.S., D’Cunha, R., D’souZA, R., BALIGA, M.S. (2018): Polyphenols in the prevention of acute pancreatitis in preclinical systems of study: a revisit. In: Watson, R.R., Preedy, V.R., Zibadi, S. (eds). Polyphenols: mechanisms of action in human health and disease, second edition. Academic Press, 3 pp. 
[32] Sánchez-Campillo, M., Gabaldon, J.A., Castillo, J., Benavente-García, O., Del Baño, M.J., Alcaraz, M., Lozano, J.A. (2009): Rosmarinic acid, a photoprotective agent against UV and other ionizing radiations. Food and Chemical Toxicology 47(2): 386-392. doi: 10.1016/j.fct.2008.11.026

[33] Silva, C.A., Silva, C.R., Véras, J.H., Chen-Chen, L., Ferri, P.H., Santos, S.C. (2014): Genotoxicity and cytotoxicity evaluation of oenothein B and its protective effect against mitomycin C-induced mutagenic action. Mutation Research 767: 8-12. doi: 10.1016/j.mrgentox.2014.04.003

[34] Singh, N.P., Mccoy, M.T., Tice, R.R., SchneIDER, E.L. (1988): A simple technique for quantitation of low levels of DNA damage in individual cells. Experimental Cell Research 175(1): 184-191.

[35] Singh, P., Rahul, M.K., Thawani, V., Sudhakar, P. (2013): Anxiolytic effect of chronic administration of gallic acid in rats. Journal of Applied Pharmaceutical Science 3(7): 101-104. doi: 10.7324/JAPS.2013.3719

[36] Stanić, S., Matić, S., Solujić, S., Milošević, T. (2009): Genotoxicity testing of the methanol extract of plant Cotinus coggygria and galic acid on Drosophila melanogaster. Archives of Biological Sciences 61(2): 261-266. doi: 10.2298/ABS0902 $261 \mathrm{~S}$

[37] Tanaka, T., Iwarta, H., Niwa, K., Mori, Y., Mori, H. (1998): Inhibitory effects of ellagic acid on N-2-fluorenylacetamide-induced liver carcinogenesis in male ACI/N rats. Japanese Journal of Cancer Research 79(12): 1297-1303. doi: 10.1111/j.13497006.1988.tb01559.x

[38] Vattem, D.A., Jang, H.D., Levin, R., Shetty, K. (2006): Synergism of cranberry phenolics with ellagic acid and rosmarinic acid for antimutagenic and DNA protection functions. Journal of Food Biochemistry 30(1): 98-116. doi: 10.1111/j.17454514.2005.00063.x

[39] Vieira, O., Escarqueil-Blanc, I., Meilhac, O., Basile, J.P., Laranjinha, J., Almeida, L., Salvayre, R., Negre-Salvayre, A. (1998): Effect of dietary phenolic compounds on apoptosis of human cultured endothelial cells induced by oxidized LDL. British Journal of Pharmacology 123(3): 565-573. doi: 10.1038/sj.bjp.0701624

[40] Wätjen, W., Michels, G., Steffan, B., Niering, P., Chovolou, Y., KampköTter, A., Tran-ThI, Q-H., ProKsCh, P., KAHL, R. (2005): Low concentrations of flavonoids are protective in rat H4IIE cells whereas high concentrations cause DNA damage and apoptosis. The Journal of Nutrition 135(3): 525-531. doi: 10.1093/jn/135.3.525

[41] WenG, S.W., HsU, S.H., LiU, H.C., Ji, B.C., LIEN, J.C., YU, F.S., LIU, K.C., LAI, K.C., LIN, J.P., ChUnG, J.G. (2015): Gallic acid induces DNA damage and inhibits DNA repair-associated protein expression in human oral cancer SCC-4 cells. Anticancer Research 35(4): 2077-2084.

[42] WÜRGLER, F.E., GRAF, U. (1985): Mutagenicity testing with Drosophila melanogaster. In: Muhammed, A., Von Borster, R.C. (eds). Basic and applied mutagenesis. Plenum Press, New York, 343 pp.

[43] YamadA, J., TOMiTA, Y. (1996): Antimutagenic activity of caffeic acid and related compounds. Bioscience, Biotechnology, and Biochemistry 60(2): 328-329. doi: 10.1271/bbb.60.328 